\title{
Business Models of "New Cooperativism" Organizations as an Instrument of Sustainable Development Stimulation
}

\author{
Submitted: 13.07.20. Accepted: 28.09.20 Paweł A. Zawiślak ${ }^{1}$
}

\section{Abstract}

Purpose: The article presents business models developed in organizations of the "new cooperativism" trend, whose application leads to a bottom-up solution of important social problems at the local level and, in a broader perspective, stimulation of sustainable development.

Methodology: The adopted methodology uses a qualitative approach. The research was conducted in the form of case studies of four organizations following "new cooperativism," based on in-depth interviews, observations, and analyses of organizational documents and various types of publicly available materials.

Findings: The study showed that "new cooperativism" organizations use in their business models the old practices developed by classical cooperatives, which work well in today's conditions and have the potential to provide a positive impact on important socioeconomic dysfunctions, which can be fully implemented through modern technologies.

Research Limitations: The limitations typical of the case study method entail the uncertainty of results replication, which disallows their broad generalization. However, the obtained results indicate the need to conduct a scientific diagnosis of emerging collaborative grassroots organizations and the importance of their participation in the three-sector economic concept of the state.

Originality: The article and its conclusions are based on empirical research of the practical effectiveness of business models used in organizations of the "new cooperativism" trend.

Keywords: new cooperativism, social entrepreneurship, the economy of cooperation.

JEL: D16, L31, P13

Kozminski University, 59 Jagiellonska St., 03-301 Warsaw, Poland; e-mail: pzawislak@kozminski.edu.pl, https://0rcid.org/0000-0002$-8165-7404$. 


\section{Introduction}

The aim of the current article is to present the organization of "new cooperativism" as initiatives capable of counteracting various socioeconomic dysfunctions: social stratification, the lack of permanent and adequately remunerated work for a growing group of people, the low quality of products available in mass channels, disruption of supply chains, community deficits, the void of ideology, and the cynicism of entrepreneurs. These dysfunctions constitute a significant threat to sustainable development, leading to the inevitable occurrence of a deep structural crisis, ultimately on a global scale (Burkitt, 2019; Rahman, 2019; Russo, 2020). The business models applied by the "new cooperativism," according to the current interpretations shaped during the clash of real socialism and free-market capitalism, place them outside the margin of effectiveness (Walczak, 2013). According to the criteria created by these interpretations, effectiveness is primarily a constantly improving financial result. Examples of "new cooperativism" organizations - managed collectively and not focused on individual profit but on the objective improvement of local community situation - may be a guideline in the search for solutions to inhibit the progression of dysfunctions and stimulate sustainable development.

The business model of each of the described organizations was developed in order to provide a social solution, but its effectiveness is conditioned by the ability to ensure financial stability in a liberal, dynamically changing environment. The essential element of this environment - the "idea of making money" (Koźmiński, 2004, p. 123) - is insufficiently recognized by these organizations. Due to its specificity - i.e. acting on a small, local scale - the "new cooperativism" movement is rarely the subject of attention of researchers, who approach the analysis of an organization from the economic and financial viewpoint. On the other hand, those who approach organizations from the anthropological and social perspective do not particularly focus on their economic performance, i.e. how organizations ensure their income.

The "new cooperativism" organizations I study are a food and a housing cooperative, a hacker collective, and a cafeteria employing people with disabilities. One can easily find much more of them. All of them are developing steadily, positively contributing their activities to the development of the community in which they operate. Their business models prove to be effective in solving local problems and in stimulating sustainable development from the bottom up. Although they are not intended to operate outside their local community, their models can be replicated with equal success by another community, elsewhere, in a different environment. My study showed that the business models of the organizations surveyed have many common features, differing 
only in terms of issues arising from the specifics of their business areas. They are equally effective in confronting the challenges they face because of the specific motivation of their members.

Using the method of multiple case studies, I examined their business models, which enable them to independently solve specific problems and maintain the welfare of their developing communities. I paid attention to their "idea of making money," which eliminates the dependence on the "goodwill" of their environment. In order to explain how they manage to do this, I will describe their functioning in more detail, considering as many factors as possible that influence and coevolve with the environment. In each case, they are different, but in each case, they have an effective, positive influence on the environment and stimulate positive social transformation.

When trying to describe the business models of the "new cooperativism" one encounters difficulty in the form of an extensive, ambiguous conceptual apparatus. Both "new cooperativism" and "business model" are concepts whose application relates to the necessity of careful clarification. Both are intuitively linked to the concept of entrepreneurship, which is also vague, even more so when used in the context of social activities. Therefore, we should begin by defining what the "new cooperativism" is and in what sense it is a form of social entrepreneurship in order to be able to further focus on the issue of understanding the "business model" in the area of social activities not aimed at making a profit as measured by the financial result. This opens a broad discussion on entrepreneurship and social economy in general.

\section{Literature Review}

\section{What Is "New Cooperativism?"}

Since 2010, scholars observe the emergence and development of food cooperatives, which organize food purchases directly from producers. Founders of these cooperatives are particularly concerned that food is produced with care for the environment and comes from local producers. This trend is described as an example of the phenomenon of "new cooperativism" (Bilewicz and Błesznowski, 2016). It refers to the original ideas of the cooperative movement, which emphasize the ethical and moral dimension. However, the movement's protagonists do not come from cooperatives. They try to find an opportunity to meet their current needs by following a model based on ethical values and care for the natural environment. They demonstrate a strong commitment in the organization of a structure based on the idea of equal opportunities, greater than can 
be observed in the currently functioning classical cooperatives. They try to act for the benefit of local communities in which they operate. This new type of activity is a direct, bottom-up response to the threats posed by "predatory" global neoliberal capitalism (Rains, 2019). The "new cooperativism" tries to oppose its effects with the aim of fighting socioeconomic stratification, poverty, and environmental destruction (Bilewicz, 2015).

The first broad conceptualization of this term can be found in the work of Marcel Vieta (Vieta, 2010), a labor sociologist and researcher of collaborative organizations in different parts of the world. Vieta defines the features of "new cooperativism" with six key features:

- "It espouses values and practices of subsidiarity and community-led development. It is entrenched deeply within surrounding communities and usually embraces clear objectives for local community development, by and for the very people affected.

- It directly responds to crises. It tends to emerge as bottom-up solutions by working people and grassroots groups to myriad challenges, especially those generated by the neoliberal capitalist model, such as rising precarity and unemployment, local economic depletion, growing marginalization, and environmental degradation. It also provides proactive, community-led alternatives to the privatization of public goods and state downloading of social services.

- It is ethical, equitable, and sustainable. Its ethical-political commitments emerge not from capitalocentric frameworks but from everyday experiences and needs. Further, it aims at a more equitable distribution of social wealth and surpluses and is driven by more ethical and sustainable engagements with the other and the planet.

- It is inclusive. Its protagonists emerge from or engage with broad coalitions of community members, multiple stakeholders, and social justice movements. At times without tight links to older cooperative or labor movements, its collective projects issue more from immediate social, cultural, economic, or environmental necessity rather than from pre-existing ideological commitments.

- It is horizontal, democratic, and co-managed. Compared to both capitalist production and to more traditional cooperative experiences, it fosters more horizontalized work processes, more gender-sensitive divisions of labor, more directly democratic decision-making, and shared forms of co-management. 
- It practices collective ownership. Its means of social, cultural, or economic production is owned collectively rather than privately" (Vieta, 2014, p. 59).

Therefore, Vieta proposes to introduce a term that can be applied not only to food cooperatives but also to a whole range of new social entrepreneurial initiatives with a bottom-up and local origin, based on do-it-yourself cooperation, with a strong ideological background (Vieta, 2014a). In fact, there are many more such organizations: housing cooperatives, hacker collectives, and so-called fab-labs, informal or formalized in various ways urban and neighborhood organizations, social cooperatives, associations, foundations, and housing cooperatives (Munoz et al., 2019). Models of conduct developed these organizations develop can then be successfully replicated in other communities that face similar problems; as evidenced not only by the growing number of food cooperatives but also by other organizations that fit the six characteristics proposed by Vieta.

For the purposes of this article, I adopt the following understanding of the term "new cooperativism:" spontaneous and cooperation-based grassroots forms of entrepreneurship, aimed at solving the perceived discrepancy between a set of values and reality, long-term oriented and using cooperation methods.

\section{Social Entrepreneurship: History}

"New cooperativism" organizations manifest socially undertaken entrepreneurial activities. The notion of "social entrepreneurship" started to function in the literature in the 1950s, in the context of the responsibility that entrepreneurs bear in connection with the impact of their activities on the broadly understood environment. The proper roots of social entrepreneurship theory can be found much earlier, for example, in Thomas Moore's famous Utopia (1516) or in The City of the Sun (1602) by Tomasso Campanella. Both representatives of the Renaissance utopian literature described societies based on closeness to nature, community, and mutual support, where the power came from and was based on the wisdom of philosophers.

Deriving from a similar intellectual tradition, utopian socialists believed that a society could be created anew based on the idea of cooperation of all its citizens. Henri de Saint-Simon, Robert Owen, or Charles Fourier arranged various projects organizing the life of communities that were to share the fruits of their work, raise children collectively, and live in harmony with nature. They have also been implemented. The "Familistère" created in the Picardy commune of Guise by a French industrialist 
fascinated with Fourier's ideas, Jean-Baptiste André Godin, functioned from the mid-nineteenth century until the outbreak of the Second World War.

Today, it is widely believed that the concepts of utopian socialists were the theoretical foundation for the cooperative movement, which contrasted to the former by its focus on direct practice. The success of one of the first food cooperatives, founded in 1844 by 28 weavers of the Rochdale Society of Equitable Pioneers, resulted from the application of self-developed general rules of conduct, later called the Rochdale Principles:

The present Co-operative Movement does not intend to meddle with the various religious or political differences which now exist in society, but by a common bond, namely that of self-interest, to join together the means, the energies, and the talents of all for the common benefit of each. 1. That capital should be of their own providing and bear a fixed rate of interest; 2 . that only the purest provisions procurable should be supplied to members; 3 . that full weight and measure should be given. 4 . that market prices should be charged and no credit given nor asked; 5 . that profits should be divided pro rata upon the amount of purchases made by each member; 6 . that the principle of "one member one vote" should obtain in government and the equality of the sexes in membership; 7. that the management should be in the hands of officers and committee elected periodically; 8 . that a definite percentage of profits should be allotted to education; 9. that frequent statements and balance sheets should be presented to members" (Fairbairn, 1994).

Regardless of Rochdale pioneers, a similar set of rules has been worked out again and again. An example is the cooperative founded in 1954 in the small town of Mondragon, in crisis after the Spanish Civil War, by Jesuit Don Jose Maria Arizmendiarreta. Originally a small cooperative producing kerosene heaters, it is now a federation of many different cooperatives employing almost 80,000 people. The Mondragon success is based on the principles developed in the first few years of its operation, which require that it should maintain independence, collective management, open membership, education, and care for the local community, just like in the Rochdale Principles (Barker, 1998). Today, after minor updates in accordance with the guidelines of the International Cooperative Union (ICA), they are the basis for every cooperative in the world.

In the example of Polish cooperative history, which takes place in conditions of all kinds of oppression, difficulties, and shortages, we may clearly see how grassroots entrepreneurship becomes an effective and universal catalyst for social improvement, based on the idea of the cooperative principles. The development of the Polish cooperative 
movement has been influenced essentially by the fact that the country was partitioned. Leading ideologists of the cooperative movement sought a way of resisting oppression that would bring better results than open armed struggle (Abramowski, 2012, p. 168). After the First World War, in newly independent Poland, the movement had the sympathy of all currents and political milieux. This included even supporters of liberal economics, for whom voluntary participation and independence "was an admirable way of stimulating economic activity and improving the economic conditions of the poorer strata” (Okraska, 2014, p. 59). During the Nazi occupation, cooperative structures made a significant contribution to the development of underground activity by organizing food supplies for the underground and providing employment, thus enabling access to food ration cards and protection against forced labor export. After the Second World War, the entire economy - including the social one - was subordinated to the state apparatus, so after the political changes of 1989, the slogans of collectivism and cooperativism were lost, evoking associations with its caricatured image created during the communist era. Today, classical cooperatives operate in many sectors of the economy: agriculture, trade, housing, health care, insurance, credit unions. However, they are more than social organizations, they are profit-oriented enterprises, and they do not emphasize their pro-social traditions. These cooperatives rarely deliberately and consciously engage in activities aimed at stimulating positive transformation and creating social value.

\section{Current Context}

Therefore, the focus of social entrepreneurship now shifted from the area of cooperatives to the sector of various NGOs, also known as the "third" or "non-profit sector." This term emphasizes its distinctiveness from state institutions and organizations operating for private profit. There are very different types of undertakings in terms of the character and form of activity: political parties, charities, hunting clubs, or for example, the Red Cross. However, these constitute a permanent and specific element of the functioning of contemporary society, having no ambition to catalyze far-reaching changes, and developing an economically selfless activity.

The notion of social activity is intuitively perceived as selfless, but this does not mean that it is not an entrepreneurial activity, which is also intuitively associated with the profit-oriented activity. Peter Drucker describes entrepreneurship as a 'meta-economic' phenomenon that shapes the economy while remaining external (Drucker, 1985). Therefore, it is perfectly understandable to link the concept of entrepreneurship with social activity. Social entrepreneurship is the art of the effective management of the social economy. "Effective" means that social entrepreneurship is oriented toward the "social 
good," whose conceptualization is based on the idea of solidarity (Spicker et al., 2007), on ties opposing liberalism which puts the interest of the individual above social interest. Achieving a specific "social good" is the mission of social organizations, and its implementation depends on the ability to act entrepreneurially. There are clear connotations of the notions of "entrepreneurship" and "entrepreneur" with active participation in economic processes. Therefore, an indispensable element of social entrepreneurial activities is seeking financial resources. Social entrepreneurship is a business practice in areas which, by their nature, are not a field of achieving individual benefits but are an indispensable element of the orderly functioning of human groups, which as such, must be managed entrepreneurially. Social entrepreneurs are trying to transform societies; their driving force is "the dream of creating an ideal society based on cooperation, mutual assistance, and equal access to power and goods" (Błesznowski, 2014, p. 7).

Let us note that mechanisms of cooperation and sharing exist and are very effectively used to make individual profits in the market. After the 2007-2009 crisis, there returned interest in the ideas of cooperativism and the memory of the cooperative movement - that creates communities based on cooperation rather than competition - has drawn many people from a deep scarcity in its over 200-year-long history. In 2011, Time magazine placed "sharing" on the list of "10 Ideas That Will Change the World;" and we could also read about the advent of a "new collective era," thanks to the combination of sharing potentials and modern technology (Rifkin, 2011, p. 16). The combination of the idea of collaboration and sharing with the bold and creative use of technology has given rise to the phenomenon of the "economy of collaboration." This phenomenon begins with the synthesis of four factors (after Botsman and Rogers, 2010):

- renewed faith in the strength of community;

- the development of social media and data transfer technologies that give all hosts the same powers, such as P2P and torrent;

- growing and widespread concern for ecosystem protection issues;

- the shock of the crisis and the global recession.

The "new cooperativism" appeared and started to develop after the 2007-2009 crisis, i.e. at the same time as the "economy of cooperation." However, there are clear differences between them. Business models of "new cooperativism" organizations base not on specially designed mobile applications - which allow for the collection of a fee for facilitating the cooperation of others - but they draw on the potential of a real, local community of people trying to solve some common problem that affects them all, just like the first classical cooperatives. The "economy of cooperation" has proved to be 
more than just a phenomenon in which private companies are developing at an astonishing speed (Martin, 2016). The essence of their business model is to set rules and conditions and to charge an intermediary service cost, but avoiding responsibility for the quality and safety of "shared" goods and services by declaring the position of "application platform operator." In the countries where these undertakings operate, there are protests by representatives of relevant industries and huge problems with adapting the tax system and labor law (Davies, 2017). There are also other conflicts of various kinds; people who "share" and "cooperate" do not have any sense of community with each other, often do not even meet (Bardhi, 2012). It goes without question that "new cooperativism" stimulates a positive social transformation, so important and underlined in all organizations that follow this trend (Geissinger et al., 2019).

\section{Social Entrepreneurship: Definitions}

The analysis of texts about economic phenomena and social entrepreneurship reveals the existence of a large number of approaches and a huge conceptual apparatus used to describe entrepreneurial activities undertaken in the social field. The phenomenon is sometimes referred to as "popular/common economy," "poor economy," "local community economy," "civic economy," "labor economy," and "cooperation economy." The scientific effort is directed toward answering: what is social entrepreneurship/social entrepreneur? What is the difference between social and commercial entrepreneurship? What are the differences between social entrepreneurship and social activity of local authorities or institutions? What are the areas and models of social entrepreneurship? What are the measures of social entrepreneurship success? The conceptualization of entrepreneurship and social enterprises can certainly be conducted in various ways, emphasizing the particular meaning aspects of the terms "entrepreneurship" and "social." Dacin, Dacin and Matear quote 37 different definitions to indicate their oversupply (Dacin et al., 2010), as we may read from the title of their publication "Social Entrepreneurship: Why We Don’t Need a New Theory and How We Move Forward from Here.”

These issues are dealt with extensively in the Social Economy quarterly Jerzy Hausner, Norbert Laurisz and Stanisław Mazur, who explain the essence of a social enterprise, its characteristics and the framework of its occurrence - it connects the third sector with the private sector, links the functioning of civil society with the market economy, taking various legal forms (Hausner et al., 2008). Next, they identify the following basic components of a social enterprise:

- offering products or services that involve economic risk and economic verification of the effects of those activities, 
- focusing activities on social integration on the scale of the local community,

- subordinating ownership relations to stakeholders' interests,

- a culture of governance embedded in partnership and participation,

- democratic control by stakeholders (Hausner et al., 2008).

An interesting approach to the essence of a social enterprise is provided by the "theory of the con-firm" presented by Adam Noga in his book Theories of Companies (Noga, 2009). Noga claims that households are treated as basic and actual components of civil society. As Florczak writes, in the theory of the con-firm "a social enterprise is an economic entity, introducing socially sensitive initiatives into the economic cycle. ... A social enterprise not only achieves household goals, but in the form of a non-governmental organization, it represents worldview aspirations. ... In such an approach, relying on the theory of the con-firm results from its inclusion of humanism and human subjectivity into economic activities" (Florczak, 2011, p. 46-47).

Following these evaluation criteria, a social enterprise is far more an organization following "new cooperativism" - such as a hacker collective or a housing cooperative - than a hunting club or a charity foundation.

\section{Business Model}

The use of the term "business model" in relation to "new cooperativism" organizations requires clarification, as it has a broad field of meaning in practice and management theory.

An example of a business model in action can be the strategy taken over at the beginning of the twentieth century by King Camp Gillette, the founder of Gillette Safety Razor Company, consisting in selling razors below production costs while making a profit from selling disposable blades for them. It is pictorially referred to as the "lure and hook model," later on, it was creatively replicated many times, taking place among other similarly defined models, e.g. "affinity club," “pay-as-you-go," or "reverse auction” (Johnson, 2010).

Theoretical studies approach the issue from e.g. product or service structure, considering the roles of business actors and how they profit or creating value by taking advantage of business opportunities. Their conceptualization, conducted for the description of functioning and planned business models, is often dominated by "design logic" (George and Bock, 2009). In explaining and describing their business model, practitioners use "engineering" rhetoric and conceptual apparatus. The popular Alexander 
Osterwalder's Business Model Canvas is a tool to support this approach. It is used to "map" and visualize existing business models and - thanks to its graphical transparency - to analyze them, providing inspiration in and framework for the design of new ones. It can be used to identify the design of many forms of business models based on electronic and ICT solutions, as it is sometimes referred to as "data monetization" (van't Spijker, 2014, p. 70). This tool has become particularly popular due to the development of the e-economy and the use of technology in market processes.

Michael Porter describes the business model as a general and often unclear concept of how a company operates, how it is placed in the "value chain," and how it generates profit, which in turn is supposed to achieve and maintain dominance over other companies, also called competitive advantage (Porter, 1996; 2001).

All the above approaches reflect the essence of the business model from a market viewpoint. However, for these approaches to be used in the description of "new cooperativism" organizations, they are too focused on building structures for achieving individual financial profit and competitive advantage, which are emphasized quite differently in the activities aimed at stimulating positive social transformation. The purpose of the existence of "new cooperativism" organizations is not to achieve an individual investor's profit measured by the financial result, but social profit measured by the effectiveness in long-term and bottom-up counteracting of the effects of a specific lack, shortage, or crisis. Thus, "new cooperativism" organizations' "business model" is a method of action adopted by small local communities, which results in the bottom-up catalysis of positive social transformation toward the elimination of a barrier, stratification, exclusion, or pillaging of resources. Therefore, or the purposes of this study, the term "business model" will be used in its most general sense as a "description of how an enterprise operates" (Arend, 2013, p. 391).

However, let us remember that financial resources remain necessary in order to achieve a social goal. Hence, in the "business model" of "new cooperativism" organizations - with their differently understood profit and special approach to the competitive position - the financial aspect is an important element understood as "a way to make money." When describing such a "business model," we consider the concept of "profit" and how achieving it should be defined in each case, in which the financial aspect is one of a number of factors. Thus, a business model is the most multifaceted and wide possible description of how organizations operate, which will best be examined by means of a case study. 


\section{Research Method}

The aim of my study was to understand the specificity of the phenomenon of "new cooperativism" from the perspective of the business model. The application of the multiple case study method to identify the predisposition of "new cooperativism" organizations to function under current socioeconomic conditions results from the nature of the undertaken task. The aim was to check to what extent different organizations are effective in solving specific problems and at the same time independent and self-sufficient. These organizations are treated in terms of orientation (branches and objectives) of their activities, yet meet the criteria contained in Vieta's six guidelines. Answers could have been obtained through induction, by generalizing from events observed in the examined organizations functioning in their natural context. In the study, observation, in-depth interviews, and analysis of organizational documents, and all other available materials were conducted to obtain empirical data in the form of texts describing the functioning of these organizations. The study of these organizations allowed me to gather material that could be used to derive generalizations concerning the confrontation of practical implementation of the "new cooperativism" theory assumptions with the challenges they face.

First, I made a deductive selection of organizations to be described based on the criteria outlined by the existing theory of "new cooperativism." Organizations meeting these criteria operate in different areas of the social economy and use different forms of legal personality. In order to find and identify appropriate organizations, I checked various types of publicly available materials - marketing, press, social networking profiles, data from the National Court Register - in which one can find information about grassroots social activities, referring in their declarations and actions to the criteria contained in the Vieta's six guidelines. The easiest organizations to notice from this perspective were food cooperatives, widely described in the local press, whose members themselves sometimes referred to "new cooperativism" (Bilewicz, 2015). However, it is not advisable to stop at food cooperatives only, because the scope of inference and generalization would quickly limit the following theoretical saturation resulting from the obvious similarities of these organizations. All food cooperatives have the same mission, differing in details related to their local specificity (Bilewicz and Śpiewak, 2015). Following the criteria contained in the "new cooperativism" theory, many other, very diverse organizations can be identified: informal groups, collectives, associations, foundations, and social cooperatives. In the materials they make available to the public, I found content referring to a bottom-up, cooperative response to social problems, a democratic style of operation, and strong links with the local environment. 
The methodological assumptions of a multiple case study allow for the use of a small number of cases that are respectively different when carrying out a generalization. My query revealed that there are many "new cooperativism" organizations in Poland: besides about 40 food cooperatives, the results are also replicated by hacker collectives (6 hackerspaces, 18 fab labs), housing cooperatives (5), and other grassroots groups formed from the bottom up to undertake joint social action. The latter consist of informal local groups that - according to their needs and stage of development - register as different legal forms: associations, foundations, worker cooperatives, social cooperatives, and even incorporated companies. In order to establish a concrete number, especially in the case of the latter, extensive and detailed quantitative studies should be carried out. Following the criteria of differentiation and uniqueness (Creswell, 2013, p. 68), I made contact with:

- Food Cooperative Dobrze from Warsaw,

- the hacker collective "Hackerspace Warsaw"

- the Równik café club from Wrocław,

- a housing cooperative from Konstancin-Jeziorna.

Participants of these organizations were interviewed based on generally formulated research problems, in which the lack of categorization of questions and arrangement of a natural conversation with the respondent fostered the disclosure of various aspects of the organization's functioning. Formulated in the following order, the topics concerned:

- the history of the organization as the history of this type of organization in general (e.g. food, housing, hacker cooperatives) and of this particular organization; its mission and vision; community characteristics; functions and activities of founders and originators; first activities; group dynamics; informal and formal structures development; the choice of legal personality; the written formulation of the organization's rules; the creation and filling of jobs; professionalization; the choice and adoption of decision-making procedures; the technologies used; technical and accommodation infrastructure;

- the motivation of organization members to create it and operate in it; perceived shortages; unmet needs; perceived crises; convictions about the purposefulness of this form of action in relation to micro and macro problems; worldview and ideological involvement; the knowledge of the history and types of social activities; leaders' functions; the notion of profit for individual members and the entire community; adopted measures of success; openness and criteria for accepting new members; 
- business model; fundraising and other resources; the environment; the offer; the competition; employment and its forms; operational management; processes and logistics; inter-organizational relations; independence and the concept of the organization's further development.

Besides interviews, I employed the data I found, i.e. press materials and any other materials, e.g. statutes, which could be accessed through the websites of surveyed organizations, along with social networking profiles and other non-confidential organizational documents, e.g. instructions, regulations, and financial statements submitted to the tax office or relevant state administration. When reviewing the above materials, I used the same thematic criteria as when formulating the questions used in the interview, by seeking data on the history of the organization, participants' motivation, and the developed business model (Gomm, Hammersley and Foster, 2011). The collected data were arranged according to the following five analytical categories, selected in the course of interviews, document analysis, and observations:

- "mission" (short-long/long-term, the type of crisis, stage objectives, history);

- "ideology" (inspirations and references, manifested beliefs, attitude to the history and tradition of cooperation);

- "business model" (legal form, offerings, risks, clients, employment, financial information, financial and resource independence, the pace and direction of development, plans and strategies);

- "management" (organization size, centralization/decentralization, leadership roles and hierarchy, structures, formalization, decision-making mode, professionalization, specific features);

- "technology" (attitude to its use, types used, relevance in the organization, innovative use, needs).

The data collected and organized in this way were subjected to triangulation by using different sources of information in parallel. They were later used to construct a detailed textual description of the functioning of surveyed organizations in the period from the moment of their creation to the moment when the survey was conducted. This description had the same text volume and structure in the case of each organization, which made it easier to later extract the variables and analyze and compare them. Thus extracted, compiled in two tables, and supplemented by a short textual description containing basic information about the described organization, the data are presented below. 


\section{Food Cooperative Dobrze (Warsaw)}

Dobrze is a food cooperative established to organize access to food from small-scale organic farms with care for several quality features and at an attractive price. Moreover, Dobrze aims at various social projects, such as creating a space for local integration, civic education, and promoting models of bottom-up action toward sustainable development. Since its establishment as one of the first organizations of this type in Poland, Dobrze has undergone development from an informal group of a few people directly buying food from small local producers to a small enterprise running two food stores in the center of Warsaw. They are characterized by an extensive management system based on mechanisms enabling equal and inclusive participation of about 300 actively cooperating members. Divided into coordination groups and employing over a dozen people based on an employment contract, they effectively maintain processes related to all typical aspects of operation for this size and field of business.

The business model of Dobrze is based on the elimination from the final price of the product normally offered in the shops of all the margins of intermediaries. Moreover, it bases on the collective sharing of the weight of organizing the value chain in exchange for the lower price for its members and non-members, acquired thanks to the attractive location in the city center of the shops. All members of the cooperative work on a parttime basis and pay an annual contribution. Acting as an association, Dobrze benefits from a few forms of external support legally vested in organizations with this form of legal personality, mainly in the form of discounts on the lease of premises from the city and crowdfunding possibilities for the organization of various events.

This type of activity provided Dobrze with stable growth and enabled it to open more stores, restrained only by ideological considerations. Dobrze constantly increases staff salaries and invests in the development of company infrastructure, but it also engages in animating the life of the local community. Dobrze is involved in building a platform for contact with other similar organizations by organizing conferences and internships.

The founders and many members of Dobrze come from urban environments, generally referred to as "alternative" or "left-wing." They are familiar with the writings of political critics from various periods, are often involved in various types of urban initiatives, and have strong convictions about employment, local networks, and ecology. 
Tables 1 and 2. Food Cooperative Dobrze (Warsaw)

\begin{tabular}{|l|l|}
\hline $\begin{array}{l}\text { Year of establishment/Formation of legal } \\
\text { personality/ Number of members }\end{array}$ & \multicolumn{2}{|c|}{$\mathbf{2 0 1 2 / a s s o c i a t i o n / 3 0 0}$} \\
\hline Objective & $\begin{array}{l}\text { organization of the system of access to specific } \\
\text { foods }\end{array}$ \\
\hline Ideological values & cooperative values \\
\hline Structure & own \\
\hline Leadership & dispersed/authority based \\
\hline Technology to support cooperation & no \\
\hline The measure of success & continuance \\
\hline
\end{tabular}

\begin{tabular}{|l|c|c|c|c|}
\hline & $\begin{array}{c}\text { Commercial } \\
\text { activities }\end{array}$ & $\begin{array}{c}\text { Institutional } \\
\text { funding }\end{array}$ & $\begin{array}{c}\text { Members' } \\
\text { contributions }\end{array}$ & $\begin{array}{c}\text { Public } \\
\text { contributions }\end{array}$ \\
\hline Location & $X$ & $\checkmark$ & $X$ & $\checkmark$ \\
\hline Equipment & $X$ & $\checkmark$ & $\checkmark$ & $X$ \\
\hline Wages & $\checkmark$ & $X$ & $\checkmark$ & $X$ \\
\hline Development & $\checkmark$ & $X$ & $\checkmark$ & $X$ \\
\hline
\end{tabular}

Source: own elaboration.

\section{Hackerspace (Warsaw)}

"Hackerspace" is the name of a shared workshop space for programmers and technicians known as hackers. Hackerspace Warsaw is an association running a workshop equipped with computer hardware and many other devices such as numerically controlled machine tools or 3D printers. The name of this organization - like many other around the world - stems from the verb "to hack," meaning in the jargon of people involved in technology and coding, "to get inside something to make modifications." The purpose of hackerspaces is to provide broad access to expensive equipment for a wide variety of activities, which until now have been reserved for a narrow circle of specialists working for public and private organizations that can afford to buy this equipment. Moreover, Hackerspace is to serve as a local platform for the contact and integration of people who deal with modern technologies, whose development is to be beneficial also from the social viewpoint, as a place for information, consultation, and education activities. 
The founders and members come from technology-oriented circles, with a large representation of technicians-programmers. They often refer to the hacker ethics, formulated in the 1980s, which postulates the dissemination of knowledge and social access to the opportunities offered by modern technology as a prerequisite for building and maintaining civil security in the dynamic development of technology. Those motivated in this way carry out many pro-social activities for their local community, which they see in a real (urban neighborhood) and virtual environment (online forums).

Hackerspace members view their activities as a passion and a source of income that simultaneously generates social benefits in the form of providing information, consultation, and assistance, and that of ongoing monitoring of the impact that technology has or may have on the functioning of civil society, e.g. from the perspective of protecting the privacy and freedom of web users.

Hackerspace Warsaw was created as an informal initiative that quickly spread among people with similar interests. It now has about 80 contributing members involved in their own projects using a jointly rented and adapted space, the equipment it contains, and the exchange of knowledge, experience, and skills. They also constantly conduct various forms of educational and consulting activities for many people willing to participate.

Their "idea of making money" is basically to support the organization with all kinds of membership contributions: work, money, or equipment. However, thanks to the possibility of access to specialized equipment and mutual support, each participant of the organization finds the means to donate to the functioning of the organization. All decisions made within the organization are based on consensus and approval of all members, achieved through a strong informal structure, in which leadership roles are based on competence and are carried out on an ad hoc basis, in connection with planned activities.

\section{Tables 3 and 4. Hackerspace (Warsaw)}

Year of establishment/Formation of legal personality/ Number of members

Objective

Ideological values

Structure

Leadership

\section{2/association/80}

organization of the life of the hacker movement hacker ethics

informal

dispersed/authority based 
Technology to support cooperation

The measure of success no

continuance

\begin{tabular}{|l|c|c|c|c|}
\hline & $\begin{array}{c}\text { Commercial } \\
\text { activities }\end{array}$ & $\begin{array}{c}\text { Institutional } \\
\text { funding }\end{array}$ & $\begin{array}{c}\text { Members' } \\
\text { contributions }\end{array}$ & $\begin{array}{c}\text { Public } \\
\text { contributions }\end{array}$ \\
\hline Location & $X$ & $X$ & $\checkmark$ & $X$ \\
\hline Equipment & $X$ & $X$ & $X$ & $X$ \\
\hline Wages & - & - & - & - \\
\hline Development & $X$ & $X$ & $\checkmark$ & $X$ \\
\hline
\end{tabular}

Source: own elaboration.

\section{Równik Café Club (Wroclaw)}

Równik a restaurant located in the Wroclaw Nadodrze district. Równik's staff are people suffering from neurological dysfunctions who participate in many years of therapy, the effects of which gave them the opportunity to take up gainful employment and gradually become self-dependent. The founders of Równik are therapists and parents, a community whose members have worked together for years, know each other well, support each other, and cooperate in "creating circumstances" conducive to therapy and the process of social integration of their patients and relatives. Moreover, they aim to raise public awareness of disability, which they see as a factor that does not necessarily eliminate from social life, and of the concept of equality as development in terms of individual opportunities.

The venue was opened in 2018 by the long-established Stowarzyszenie Twórców i Zwolenników Psychostymulacji (STZP; Association of Creators and Supporters of Psychostimulation). However, when Równik started to operate, the informal structure - effective in the face of the challenges faced by the organization - has developed significantly, which is not included in any relevant document. Current and operational decisions are made according to the competencies of relevant individuals, and a consensus is conclusive in general and directional issues, relatively easy to reach due to the size of the environment and its long history. The participants of the organization play different roles in its operation: as creators of the method working on its development, as practitioners, as parents of children with disabilities, and as families of people who completely or partially lost their ability to communicate due to injury or illness; 
each case has a different but positive impact on the motivation of members to work for the organization.

So far, STZP has trained 13 waiters, eight of whom work at Równik, which is means they serve clients. The rest of them are employed in the nearby headquarters of the Association, where they perform office work and take care of junior participants, who are at earlier stages of therapy.

Równik is formally a member of STZP and operates based on a declared form of profit-making activity for statutory purposes. In 2019, Równik employed full-time a group of eight people based. All of them are members of the STZP, and they provide customer service at Równik. The menu consists of a simple breakfast and lunch dishes, along with desserts and drinks prepared on the spot by members of the Association; prices are below average, which translates into the interest of customers. The venue also often hosts cultural events: performances, shows and concerts. Income from the events - which usually involve several dozen people - is used to develop Równik activities. Moreover, STZP benefits from numerous forms of statutory support. The premises were made available by the city authorities on preferential terms. The Association obtained an EU start-up grant and has launched a crowdfunding campaign to raise funds for the renovation and adaptation of the rented space, which was jointly prepared by its members.

\section{Tables 5 and 6. Równik Café Club (Wrocław)}

\begin{tabular}{|l|l|}
\hline $\begin{array}{c}\text { Year of establishment/Formation of legal } \\
\text { personality/ Number of members }\end{array}$ & \multicolumn{2}{|c|}{$\mathbf{2 0 1 8 / \text { association/about } 1 0 0}$} \\
\hline Objective & $\begin{array}{l}\text { social and vocational rehabilitation of the } \\
\text { disabled }\end{array}$ \\
\hline Ideological values & belief in cooperation \\
\hline Structure & informal \\
\hline Leadership & dispersed/authority based \\
\hline Technology to support cooperation & no \\
\hline The measure of success & continuance \\
\hline
\end{tabular}

\begin{tabular}{|l|c|c|c|c|}
\hline & $\begin{array}{c}\text { Commercial } \\
\text { activities }\end{array}$ & $\begin{array}{c}\text { Institutional } \\
\text { funding }\end{array}$ & $\begin{array}{c}\text { Memberss' } \\
\text { contributions }\end{array}$ & $\begin{array}{c}\text { Public } \\
\text { contributions }\end{array}$ \\
\hline Location & $X$ & $\checkmark$ & $\checkmark$ & $\checkmark$ \\
\hline Equipment & $\checkmark$ & $\checkmark$ & $X$ & $\checkmark$ \\
\hline
\end{tabular}




\begin{tabular}{|l|l|l|l|l|}
\hline Wages & $\checkmark$ & $\checkmark$ & $x$ & $x$ \\
\hline Development & $x$ & $\checkmark$ & $\checkmark$ & $x$ \\
\hline
\end{tabular}

Source: own elaboration.

\section{Housing Cooperative Konstancin-Jeziorna}

The Housing Cooperative Konstancin-Jeziorna was established in 2016 in order to build affordable housing for its members, which will meet certain criteria related to size and location. These are eight families whose members know each other and trust each other in connection with their joint participation in a religious movement. The Cooperative is completely informal if you do not count the notarial cooperation agreement that its members signed for the purpose of obtaining a building loan separately for each family in a bank. Its members bought from their own resources a suitable, jointly selected plot of land with the intention of building a multi-family residential building on it, in accordance with an architectural concept adopted by all members, which assumes the subsequent separation of ownership of the premises.

The Cooperative delegated one of its members to manage construction works, giving this person broad prerogatives to represent other members of the Cooperative to external contractors, architects, engineers, and any other persons and entities involved in the construction, along with the authorities - also when signing the building permit application. Moreover, this person was responsible for planning and financial control, preparing and conducting meetings of the Cooperative's members, informing about the progress and costs of the construction, and for settling the investment. This person was granted the above rights due to his education in engineering, and the function was called "substitute investor." The construction was completed in 2018, and the members of the cooperative are now jointly managing the property, taking all decisions by consensus, which is easy to reach due to the small size of the community.

The motivation to establish a cooperative was based on the possibility of achieving financially and organizationally attractive investment conditions, whose success was guaranteed by the bond resulting from a common worldview and participation in a religious community. Currently, the members of the cooperative provide information and share their experience with several other housing cooperatives, mainly in how to receive bank loans and manage construction through a "substitute investor" that represents all members of an organization. 
Tables 7 and 8. Housing Cooperative Konstancin-Jeziorna

\begin{tabular}{|l|l|}
\hline $\begin{array}{l}\text { Year of establishment/Formation of legal } \\
\text { personality/ Number of members }\end{array}$ & 2017/residential community/8 families \\
\hline Objective & housing construction \\
\hline Ideological values & Christian values \\
\hline Structure & informal \\
\hline Leadership & dispersed/authority based \\
\hline Technology to support cooperation & no \\
\hline The measure of success & goal achievement \\
\hline
\end{tabular}

\begin{tabular}{|l|c|c|c|c|}
\hline & $\begin{array}{c}\text { Commercial } \\
\text { activities }\end{array}$ & $\begin{array}{c}\text { Institutional } \\
\text { funding }\end{array}$ & $\begin{array}{c}\text { Members' } \\
\text { contributions }\end{array}$ & $\begin{array}{c}\text { Public } \\
\text { contributions }\end{array}$ \\
\hline Location & $X$ & $X$ & $\checkmark$ & $X$ \\
\hline Equipment & $X$ & $X$ & $\checkmark$ & $X$ \\
\hline Wages & - & - & - & - \\
\hline Development & $X$ & $X$ & $\checkmark$ & $X$ \\
\hline
\end{tabular}

Source: own elaboration.

\section{Discussion}

Due to the low level of standardization of results obtained and the small number of examined organizations - characteristic for the adopted methodology - the analysis of data contained in tables and abbreviated case study texts boils down to indicating similarities and differences between the examined organizations. Furthermore, I compared specific features of the examined organizations, which are important from the viewpoint of the assessment of their predisposition to functioning in the current socioeconomic conditions, and which leads to a specific conclusion.

Similarities among the studied organizations:

- created after 2010;

- small in scale (up to several hundred people) and based on local links;

- the dominance of the informal structure over the legal form structure, treated instrumentally; 
- leadership based on authority, knowledge, skills, and collective decision-making;

- motivation based on values and willingness to strengthen the local community;

- the measure of success is "persistence," expansive development, and the perception of competitive as inexpedient;

- a small but noticeable role of modern technologies, especially in communications;

- the use of community funding, member contributions, in-kind contributions, and work.

Differences among the studied organization:

- industry, purpose, fields of activity;

- the occurrence of employment;

- commercial activities;

- not all benefit from institutional funding;

- not all benefit from social funding.

The studied organizations differ from each other but have more similarities. All of them were created in a specific social group, affected by a common problem, for which the public and market sector did not provide a satisfactory solution from the perspective of their members.

\section{Structure}

The members of these organizations often stress that the formal structure resulting from the adopted legal personality - statutory prerogatives of management boards, managers, controlling bodies - is treated instrumentally, as a path to legalization, necessary or useful to achieve the organization's objective. Existing selectable legal forms often do not fit the nature of the organization. The reason is the need to operate a large administrative and bureaucratic apparatus or a statutorily imposed decision-making mode and the structure of the division of duties and powers, which for ideological - but also practical - reasons are constructed in a special way in the examined organizations. This results in the development and practical superiority of the informal structure, specified and "formalized" internally, by means of intra-organizational documents: regulations, instructions, duty lists.

\section{Leadership and Decision-Making}

Leadership roles in the organization are also not related to the position held in the organization's formal structure, which results from the legal form they choose. The 
roles are achieved through - and relate to - knowledge, skills, commitment, and initiative. The field of activity of these types of leaders is defined in various ways by groups coordinating the service or the execution of a task. These are often made up of people who show predispositions for a task, and their functioning can be described by means of roles and a pattern of team behavior known from the literature.

Operational decisions are the competence of teams and task coordination groups, but serious decisions - concerning the direction of development or other broader and general issues - are taken democratically, with a great effort to involve all participants of the organization. This is achieved in almost every case, often through carefully developed decision-making mechanisms. However, it is also important that the described organizations are small, while their participants know each other and are guided by ideological considerations, their values, the sense of community, and their relationship with the environment in which their organization operates.

\section{Motivation and Measures of Success}

These factors also have a strong influence on the willingness to act at the beginning, when the organization is first established and requires much enthusiasm. With the professionalization and gradual development of a routine, the developed mechanisms consolidate in various organizational documents (regulations and instructions), but the quality of engagement is still affected by the ideological approach and strong conviction of the right course of action. This conviction is also influenced by the effectiveness of activities - proportional to the costs - and the positive perception of the organization by the local environment, present in each of the described cases.

The measure of success of the described organizations used by the participants is the very existence - "survival" - of the organization and fulfillment of its task in the subjective perception of members and their immediate environment. Let us note here that the goal of these organizations - the "profit" that the participants want to achieve from them - is not constant growth in comparison to the competition and the achievement of a dominant position in the environment by multiplying and accumulating capital.

\section{Business Model}

Unlike those of the so-called "economy of sharing," the development and functioning of the studied organizations are not particularly affected by modern technologies. They do not use any applications designed especially for them or equipment that stands out and is specific to the industry in which they operate. Rather, we may speak of an 
indirect influence of technology, consisting in the fact that today almost everyone uses the Internet, including the participants of the "new cooperativism" organization, which in their case is a source of knowledge and inspiration. The Internet gives those who want to find valuable information materials and share them in their environment.

The described organizations differ in their field of activity. It is different in terms of operational management, processes, and management methods. Not in every case there is a focus on profit-making activities, even for statutory purposes. One of the four examined organizations functions only thanks to members' contributions and - in special cases - a small form of external support. In this case, however, there is no intention to create employment of any kind.

The most important thing from the viewpoint of the business model conceptualization understood as the "idea of making money" by the described organizations is that they all benefit from some form of "participant contributions," understood as financial, in-kind, work, or their combination. The assets and resources necessary for the operation of the described organizations are all ordinary inputs needed for the operation of a 'classical' enterprise. Moreover, these organizations face the same costs. If wages and salaries are paid, they are based on funds from a specific form of gainful activity. Other ways of obtaining funds are to use the funding available in accordance with the adopted legal form: grants, subsidies, or various types of reliefs and benefits from diverse institutions, along with the developing system of public collections supported by IT solutions called crowdfunding. The organizations described above benefit from these forms of funding but try to ensure that their existence does not depend on them.

\section{Implications for Theory and Practice}

Following the criteria contained in the six guidelines proposed by M. Vieta, many organizations fit into the pattern of "new cooperativism." They are created from the bottom up in many areas of social life as an attempt to counteract a wide spectrum of problems affecting small local communities. Their character is not shaped by an attitude toward achieving individual profit but profit in the social dimension. Their way of acting locally prevents marginalization (through inclusiveness and models of deeply democratic management), stratification (through a model of action not aimed at capital accumulation), the disintegration of local relationships, and the degradation of the natural environment (through functioning based on local resources). It constitutes the essence of general social entrepreneurship, deeply rooted in the literature (including the utopian one) and tradition (including that of idealism). 
According to the current theory, social entrepreneurship is to be complementary to private and public enterprises. It is not intended to substitute or replace the free market or the public economy, being only "their relatively narrow supplement" (Hausner, 2007, p. 12). However, the dominance of the free market and state economy organized following the free-market model is the cause of many crises, which can be effectively counteracted by bottom-up cooperation. The business models of "new cooperativism" provide two practical guidelines as to how to do this effectively and efficiently in the situation of lacking access or excessive costs of specific goods and services.

First, all the surveyed organizations achieve their goals and successfully accomplish a socially desirable mission through direct democratic governance, which works because the described communities are local and small. Their members are people with different ties to the organization - including emotional ones - and its immediate environment, which positively influences their attitudes and motivation. The effectiveness of such management and decision-making methods is generally rejected as causing organizational slowdown and paralysis. However, the examples of "new cooperativism" organizations seem to contradict this view, even if it takes "growth" as a measure of success. The "growth” is sustainable in their case because its beneficiaries are all members of the same community, and it does not cause dangerous side effects for the overall balance.

Second, all members benefit from the voluntary support of their own members, who contribute with their knowledge, work, and subjects in the form of a financial contribution and, most often, their combination. The studied organizations sometimes use external support, but only occasionally. The members of these organizations are willing to make contributions as they are rewarded for them.

The effectiveness of business models based on cooperation in achieving social goals has been proven in practice many times in the past and in countless postulative and normative approaches - from political thought (Abramowski, 1924) through theology (Ratzinger, 1999) to modern sociology (Sennett, 2013) - although it remains absent from most of business school textbooks and classes. A noteworthy feature of cooperation and collaboration manifesting itself in "new cooperativism" organizations is the fact that their ideals fit into different worldviews, usually in sharp opposition. The model of cooperation, based on the determinants formulated by Vieta, is equally well accepted in left-wing and conservative circles.

In "new cooperativism" organizations, all processes are based on authentic, genuine, non-intermediate cooperation among members of local communities, unlike companies 
such as Uber and Airbnb, which charge a commission for providing a platform-application that enables casual people to collaborate on an occasional basis. In the surveyed organizations, application platforms are not used to create structures or generate value. Whether the further development of "new cooperativism" collaborative organizations at the service of small local communities will be supported by modern technologies - as predicted by the authors of many theoretical studies, such as Botsman and Rogers (2010), Scholz and Schneider (2016), or Jemielniak and Przegalińska (2020) - is not clear in the light of the results of research conducted for the purposes of this study. In "new cooperativism" groups, there continues a discussion about acting via application platforms and their potential role as an amplifier of business models (Fedosov et al., 2019). These organizations have ambitions to improve the situation in their immediate environment, where actions using specially created digital tools are not applicable. Whereas broader positive social impacts will be the result of a possible subsequent increase in the spread of cooperation at the local level in many communities - perhaps thanks to technology - as was the case with the first cooperatives, whose models of operation spread in various ways. The vertical integration of food supply chains, which is to contribute to the stimulation of sustainable development (Antonowicz and Jastrzębowski, 2018), is largely achieved through the use of appropriate IT tools.

Therefore, "new cooperativism" is another name for an old recipe, an example of grassroots entrepreneurship, used many times in the past in the face of elite's malpractice aimed at the accumulation of capital and power at the expense of society.

\section{References}

Abramowski, E. (2012). Braterstwo, solidarność, współdziałanie. Pisma spółdzielcze i stowarzyszeniowe. Warszawa: Obywatele obywatelom.

Abramowski, E. (1924). Ideje społeczne kooperatyzmu. Warszawa: Związek Polskich Stowarzyszeń Spożywców.

Amit, R. and Zott, Ch. (2017). Business Model Innovation: How to Create Value in a Digital World. GfK Marketing Intelligence Review, 9(1). https://doi.org/10.1515/gfkmir-2017-0003.

Antonowicz, M. and Jastrzębowski, S. (2018). Innovative Models of Supply Chain Management. Central European Management Journal, 26(2), 2-15. https://doi.org/10.7206/jmba.ce.2450-7814.225.

Arend, R. (2013). The business model: Present and future - beyond a skeuomorph. Strategic Organization, 11(4), 390-402. https://doi.org/10.1177/1476127013499636.

Bardhi, F. and Eckhardt, G.M. (2012). Access-Based Consumption: The Case of Car Sharing. Journal of Consumer Research. December.

Barker, J.A. (1997). The Mondragon Model A New Pathway for the Twenty-First Century. In: R. Beckhard, M. Goldsmith and F. Hesselbein, The organization of the future. San Francisco, Calif: Jossey-Bass. 
Bilewicz, A. (2015). W stronę gospodarki społecznie zanurzonej? Kooperatywy spożywcze w Polsce. $\mathrm{PhD}$ thesis, ISS UW.

Bilewicz, A. and Błesznowski, B. (2016). Nadchodzi nowy kooperatyzm. Notes na 6 tygodni, 108.

Bilewicz, A. and Śpiewak, R. (2015). Enclaves of activism and taste: Consumer cooperatives in Poland as alternative food networks. Socio.hu, 3, 145-166. https://doi.org/10.18030/socio.hu.2015en.145.

Błesznowski, B. (red.).(2014). Kooperatyzm, spółdzielczość, demokracja. Wybór pism. Warszawa: Wydawnictwo UW. https://doi.org/10.31338/uw.9788323515067.

Botsman, R. and Rogers, R. (2010). What's Mine Is Yours: The Rise of Collaborative Consumption. New York: HarperCollins Publishers.

Burkitt, I. (2019). Alienation and emotion: social relations and estrangement in contemporary capitalism. Emotions and Society, 1(1), 51-66. https://doi.org/10.1332/263168919X15580836411841.

Creswell, J.W. (2013). Qualitative Inquiry Research Design. Choosing Among Five Approaches. London: SAGE Publications Inc.

Dacin, P.A., Dacin, M.T. and Matear, M. (2010). Social Entrepreneurship: Why We Don't Need a New Theory and How We Move Forward From Here. Academy of Management Perspectives, 24(3), 38-40. https://doi.org/10.5465/amp.24.3.37.

Davies, R. (2017). Uber loses appeal in UK employment rights case. The Guardian, 10.11.2017. https://www.theguardian.com/technology/2017/nov/10/uber-loses-appeal-employment-rights-workers.

Drucker, P. (1992). Innowacja i przedsiębiorczość. Praktyka i zasady. Warszawa: Polskie Wydawnictwo Ekonomiczne.

Fedosov, A., Lampinen, A., Dillahunt, T., Light, A. and Cheshire, C. (2019). Cooperativism and Human-Computer Interaction. CHI EA '19: Extended Abstracts of the 2019 CHI Conference on Human Factors in Computing Systems. https://doi.org/10.1145/3290607.3311751.

Florczak, E. (2011). Przedsiębiorstwo społeczne w teorii konfirmy. Kwartalnik Nauk O Przedsiębiorstwie, 20(3), 40-47. https://econjournals.sgh.waw.pl/KNoP/article/view/2077.

Geissinger, A., Laurell, Ch., Oberg, Ch. and Sandstrom, Ch. (2019). How sustainable is the sharing economy? On the sustainability connotations of sharing economy platforms. Journal of Cleaner Production, 206, 419-429. https://doi.org/10.1016/j.jclepro.2018.09.196.

George, G. and Bock, A. (2009). The business model in practice and its implications for entrepreneurship research. Entrepreneurship Theory and Practice, 35(1), 83-111.

Hausner, J. (2007). Systemowe usytuowanie ekonomii społecznej. In: Hausner, J. (ed.), Ekonomia społeczna a rozwój. Kraków: Małopolska Szkoła administracji Publicznej Uniwersytetu Ekonomicznego.

Hausner, J., Laurisz, N. and Mazur, S. (2008). Przedsiębiorstwo społeczne - konceptualizacja. In: J. Hausner (ed.), Zarzqdzanie podmiotami ekonomii społecznej. Kraków: Małopolska Szkoła Administracji Publicznej Uniwersytetu Ekonomicznego.

Jemielniak, D. (2012). Badania jakościowe. Metody i narzędzia. Vol 2. Warszawa: Wydawnictwo Naukowe PWN.

Jemielniak, D. and Przegalińska, A. (2020). Collaborative Society. Cambridge: MIT Press. https://doi.org/10.7551/mitpress/11587.001.0001.

Kardas, M. (2016). Pojęcia i typy modeli biznesowych. In: K. Klincewicz (ed.), Zarzq̨dzanie, organizacje i organizowanie - przegląd perspektyw teoretycznych. Warszawa: Wydawnictwo Naukowe Wydziału Zarządzania Uniwersytetu Warszawskiego.

Kostera, M. (2020). By odkupić duszę zarzqdzania. Obywatel. https://magazynkontakt.pl/by-odkupic-dusze-zarzadzania/. 
Koźmiński, A.K. (2004). Zarzq̨dzanie w warunkach niepewności. Podręcznik dla zaawansowanych. Warszawa: Wydawnictwo Naukowe PWN.

Martin, Ch. (2016). The sharing economy: A pathway to sustainability or a nightmarish form of neoliberal capitalism? Ecological Economics, 121(2016), 149-159. https://doi.org/10.1016/j.ecolecon.2015.11.027.

Morozov, E. (2015). Szwindel Ubera, kant Facebooka. Gazeta Wyborcza Magazyn Świąteczny. https://wyborcza.pl/magazyn/1,124059,18111508,Szwindel_Ubera_kant_Facebooka.html.

Munoz, P., Kimmitt, J. and Dimov, D. (2019). Packs, Troops and Herds: Prosocial Cooperatives and Innovation in the New Normal. Journal of Management Studies, 57(3), 470-504. https://doi.org/10.1111/joms.12542.

Noga, A. (2009). Teorie przedsiębiorstw. Warszawa: Polskie Wydawnictwo Ekonomiczne.

Nowak, E. (2016). Analiza kosztów w ocenie działalności przedsiębiorstwa. Warszawa: Wydawnictwo CeDeWu.

Okraska, R. (2014). Od samopomocy do wizji nowego ustroju. In: B. Błesznowski (ed.), Kooperatyzm, spółdzielczość, demokracja. Wybór pism. Warszawa: Wydawnictwo UW.

Porter, M. (1996). What is Strategy? Harvard Business Review. November-December.

Porter, M. (2001). Strategy and the Internet. Harvard Business Review. March.

Rains, P. (2019). Worker Cooperatives: The Default Alternative to Predatory United States Capitalism. Socialism and Democracy, 33(1), 112-140. https://doi.org/10.1080/08854300.2019.1653627.

Rahman, S.K. and Thelen, K. (2019). The Rise of the Platform Business Model and the Transformation of Twenty-First-Century Capitalism. Politics \& Society, 47(2), 177-204. https://doi.org/10.1177/0032329219838932.

Rifkin, J. (2011). Trzecia rewolucja przemysłowa. Warszawa: Sonia Draga.

Russo, A. (2020). Hyper-globalization and capitalism: socio-political effects of the international commerce. International Journal of Sociology and Social Policy, Vol. ahead-of-print No. ahead-of-print. https://doi.org/10.1108/IJSSP-04-2020-0128.

Rutka, R. and Wróbel P. (eds.) (2012). Organizacja zachowań zespołowych. Warszawa: Polskie Wydawnictwo Ekonomiczne.

Sennett, R. (2013). Razem. Rytuały, zalety i zasady współpracy. Warszawa: Wydawnictwo Literackie Muza SA.

Scholz, T. and Schneider, N. (eds.) (2016). Ours to hack and own. The rise of platform cooperativism, a new vision for the future of work and a fairer internet. New York: OR Books. https://doi.org/10.2307/j.ctv62hfq7.

Spicker P., Álvarez Leguizamón S. and Gordon D. (2007). Poverty: An International Glossary. London: Zed Books.

Spijker, A. van’t (2014). The New Oil: Using Innovative Business Models to turn Data Into Profit. New York: Technics Publications.

Thugutt, S. (1945). Spółdzielnia spożywców w Rochdale i zasady roczdelskie. Wykłady o spółdzielczości. London: Towarzystwo Kooperatystów Polskich w Wielkiej Brytanii.

Vieta, M. (2010). The New Cooperativism. A Journal of Radical Theory, Culture, and Action. 4(1), 1-11. https://doi.org/10.7206/mba.ce.2084-3356.72.

Vieta, M. (2014). The stream of self-determination and autogestión: Prefiguring alternative economic realities. Ephemera. Theory and politics in organization, 14(4), 781-809.

Walczak, W. (2013). Failures of Corporate Governance in Housing Cooperatives - Case Study. Central European Management Journal, 21(3). https://doi.org/10.7206/mba.ce.2084-3356.72. 